\title{
INHERITANCE OF OIL YIELD AND ITS COMPONENTS IN SAFFLOWER (Carthamus tinctorius L.)
}

\author{
Arzu KOSE \\ Transitional Zone Agricultural Research Institute, Eskisehir, TURKEY \\ *Corresponding author: arzukose.tr@gmail.com
}

Received: 19.02.2019

\begin{abstract}
In this research, a diallel cross consisting of genetically diverse six parents (Es-8517, Emek-16, Ekak-7, Emek21, Ekay-1, Emek-24) was used, aimed to obtain estimates of the gene action in terms of plant height, first branches height, head diameter, 1000 seed weight, oil content, oil yield of per plant in safflower by using JinksHayman type analyses. This study was conducted Transitional Zone Agricultural Research Institute Eskisehir, Turkey during 2016 and 2017. According to the results of all diallel crosses, environmental variance (E), additive gene variance $(D)$, dominance gene variance $\left(H_{1}\right),\left(H_{2}\right)$ and the value of interaction of additive $x$ dominance gene variance effect $(F)$ were found significant statistically studied traits expect head diameter. Of all the traits studied, being larger dominant gene variances $\left(H_{1}\right)$ than the additive gene variances $(D)$ and negative $D-H_{1}$ value indicated the more important role of dominant genes. Beside of these, positive $F$ value shows that dominant alleles are greater than the number of recessive alleles. Result of $\mathrm{Wr}, \mathrm{Vr}$ graphics indicated partial dominancy for the first branch height, head diameter, and over dominancy for the rest of the studied traits. It was determined that plant height, first branches height, head diameter, 1000 seed weight, oil content, oil yield of per plant had low narrow heritability values. According to results to obtain superior plants in this hybrid population to perform single plant selection in $F_{3}$ and $F_{4}$ generations would be more appropriate.
\end{abstract}

Key words: Diallel, Gene action, Inheritance, Safflower, Traits

\section{INTRODUCTION}

Safflower, a member of the Compositae family is a broadleaf, highly branched and annual industrial plant. The plant is grown for its seed and petal, especially. Safflower petal is used in fabric dyes, food coloring and treatment of some illnesses. The oil contained in its seed is used for human nutrition and biodiesel production.

Nowadays safflower has been gaining increasing popularity in the world. This situation has accelerated in breeding program aimed to improve adaptable highyielding safflower cultivars. Success of breeding research depends on range of variation studied plant material. Crossing method is mostly used in breeding programs to create new variations. Therefore, breeders aim to make crosses and benefit to them. Parent selection with desirable traits and crossing among them is an important procedure for increased production but it is difficult to choose among many crosses that seem produce outstanding offspring (Golparvar, 2014). Beside of this choosing accurate parental lines and selection of promising crosses in early generations may diminish labor, time, and high costs of breeding program. Yield and yield connected attributes are complicated quantitative traits managed by various genes. Determination of inheritance of examining traits and the knowledge of nature and magnitude of gene action of yield and its relationship with other traits are important for plant breeding (Bendjama et al., 2014). Different methods are utilized in determination of the genetic parameters. Especially, Jinks-Hayman diallel analysis method is used in the world for these aims.

Hayman's (1954) lets genetic analysis of the $F_{1}$ and/or $\mathrm{F}_{2}$ generations made from crosses including homozygote parents (Khan et al., 2009; Metwali et al., 2014). By using this model; degree of dominance, ratio of dominant to recessive alleles, number of effective factors, and the broad and narrow-sense heritability can be determined (Jinks and Hayman, 1953; Hayman, 1954; Jinks, 1954).

In this study, a $6 \times 6$ half diallel combinations of parents and populations was studied by using Jinks-Hayman type analysis aimed to determine the genetic parameters and inheritance of oil yield and its components initialing breeding program in safflower (Carthamus tinctorius L.). 


\section{MATERIALS AND METHODS}

In this study was carried out at the Transitional Zone Agricultural Research Institute, (3945"57' N, 30²4" 5' E) in Eskisehir, Turkey during 2016 and 2017. The 6 diverse parents (Es-8517, Emek-16, Ekak-7, Emek-21, Ekay-1, Emek-24) were selected for safflower breeding program aimed to developed high yielding safflower varieties. These genotypes attract attention by cold tolerant, high oil and yields. In parents, Es-8517, Ekak-7, Ekay-1 high yielding genotypes, especially Ekak-7, Ekay-1 are cold tolerant. Emek-16, Emek-21 and Emek-24 are genotypes with high oil content. The parents were planted on 15 March 2016 and diallel crosses were done between them in half diallel method to produce $F_{1}$ seeds. In 2017, 6 parents and their half diallel crosses ( 15 crosses) totally 21 genotype were sown in a randomized complete blocks design with three replications. Each of genotype was sown in plots with 4 rows; plots were $2 \mathrm{~m}$ long, with $45 \mathrm{~cm}$ between rows and $25 \mathrm{~cm}$ between plants within rows in randomized block design with four replications. At seeding, $80 \mathrm{~kg} \mathrm{ha}^{-1}$ nitrogen and $60 \mathrm{~kg} \mathrm{ha}^{-1}$ phosphorus were applied. During growing season weeds were controlled by hand.

Randomly selected twenty plants per plot were used to determine yield characters. The followed data was measured plant height, first branches height, head diameter, 1000 seed weight, oil content and oil yield of per plant. Plants were harvested in August. Oil content of genotype was determined by using Soxhlet apparatus.

Mean values of studied characters obtained from $15 \mathrm{~F}_{1}$ crosses and 6 parents were used to analyze the variation according to Jinks and Hayman (1953) diallel method. Validity of hypothesis was checked, after identifying significant statistical differences between parents and among the crosses (Hayman 1954). Graphical analysis of gene action and determination of genetic components of variation were also carried out, according to Hayman (1954) and Jinks (1954). Statistical analysis was performed by using TARPOPGEN statistical package program (Ozcan and Acıkgoz, 1999).

\section{RESULT AND DISSUSION}

To perform the Jinks-Hayman type analysis, it is essential that the validity of the assumption was checked. According to the results of the variance analysis, all genotypes showed differences with respect to the traits studied (Table 1). This result revealed that genetic structure and character inheritance could be examined in the population studied (Jinks and Hayman, 1953; Hayman, 1954; Jinks, 1954). Beside of this, validation of assumption in population studied is too significant in terms of the reliability of estimated parameters. In this research validation of these assumptions was checked in 2 ways (Yildirim et al., 1979).

Table 1. Mean sum of squares of the measurements

\begin{tabular}{lllccccc}
\hline Sources & SD & $\begin{array}{l}\text { Plant } \\
\text { height }\end{array}$ & $\begin{array}{l}\text { First branches } \\
\text { height }\end{array}$ & $\begin{array}{l}\text { Head } \\
\text { diameter }\end{array}$ & $\begin{array}{l}\text { 1000 seed } \\
\text { weight }\end{array}$ & $\begin{array}{l}\text { Oil } \\
\text { content }\end{array}$ & \multicolumn{2}{c}{$\begin{array}{l}\text { Oil yield per } \\
\text { plant }\end{array}$} \\
\hline Block & 2 & 22.87 & 10.40 & 0.126 & 17.10 & 5.17 & 0.213 \\
Genotype & 20 & $52.70^{* *}$ & $191.44^{* *}$ & $0.048^{* *}$ & $20.80^{* *}$ & $20.69^{* *}$ & $6.464^{* *}$ \\
Error & 40 & 26.43 & 39.59 & 0.020 & 4.315 & 4.03 & 1.397 \\
\hline
\end{tabular}

According to $\mathrm{Wr}, \mathrm{Vr}$ variance analysis results the $\mathrm{F}$ values educed from $\mathrm{Wr}-\mathrm{Vr}$ variance analysis of $\mathrm{F}_{1}$ populations was found not significant. These results revealed that $\mathrm{Wr}, \mathrm{Vr}$ variation differences are uniform. Therefore, means of the three replications were used to do genetic analysis (Table 2).
Wr, $\mathrm{Vr}$ regression values defined with regression analysis and $t$ values calculated for $b=1$ hypothesis are showed (Table 3). Based on the results, it was determined that the hypothesis $b=1$ is appropriate.

Table 2. Sum of squares for Wr, Vr variances

\begin{tabular}{lllrrrrr}
\hline Sources & SD $\begin{array}{l}\text { Plant } \\
\text { height }\end{array}$ & \multicolumn{2}{l}{$\begin{array}{l}\text { First branches } \\
\text { height }\end{array}$} & $\begin{array}{l}\text { Head } \\
\text { diameter }\end{array}$ & $\begin{array}{l}\text { 1000seed } \\
\text { weight }\end{array}$ & $\begin{array}{l}\text { Oil } \\
\text { content }\end{array}$ & \multicolumn{1}{l}{$\begin{array}{l}\text { Oil yield } \\
\text { per } \\
\text { plant }\end{array}$} \\
\hline Replication & 2 & 2084.69 & 10.402 & 0.1264 & 25.7569 & 101.145 & 0.514 \\
Series & 5 & 1053.61 & 191.449 & 0.0488 & 20.8397 & 82.807 & 4.309 \\
Error & 10 & 888.34 & 39.591 & 0.0209 & 18.8263 & 28.136 & 1.217 \\
\hline
\end{tabular}

Table 3. Regression values calculated from means (Wr. Vr) of the blocks and $t$ values calculated for $b=1$ hypothesis

\begin{tabular}{lcc}
\hline Features & b & t \\
\hline Plant height & $-0.554 \pm 0.414$ & 3.750 \\
First branches height & $-0.050 \pm 0.232$ & 4.526 \\
Head diameter & $-0.149 \pm 0.254$ & 4.524 \\
1000 seed weight & $0.853 \pm 0.476$ & 0.309 \\
Oil content & $0.342 \pm 0.202$ & 3.266 \\
Oil yield per plant & $1.008 \pm 0.348$ & -0.023 \\
\hline
\end{tabular}


In this study environmental variance $(\mathrm{E})$, additive gene variance $(D)$, dominance gene variance $\left(\mathrm{H}_{1}\right),\left(\mathrm{H}_{2}\right)$ and the value of interaction of additive $\mathrm{x}$ dominance gene variance effect $(\mathrm{F})$ were found significant statistically studied traits expect head diameter (Table 4). These results showed importance of both additive and dominance gene action in the genetic control of this trait. Of all the traits studied, being larger dominant gene variances $\left(\mathrm{H}_{1}\right)$ than the additive gene variances (D) and negative $\mathrm{D}-\mathrm{H}_{1}$ value indicated the more important role of dominant genes. Gupta and Singh (1988) reported that dominant gene effects controlled 1000 seed weight and oil content. Shahbazi and Saeidi (2007) reported that dominance ratio was less than unity of 1000 seed weight that was similar to our results. Golkar et al. (2012) revealed that additive gene effects were more important than dominance gene effect in governing plant height and 1000 seed weight in safflower.

Table 4. Variance components of the $6 \times 6$ half diallel safflower cross populations

\begin{tabular}{|c|c|c|c|c|c|c|}
\hline Parameters & Plant height & $\begin{array}{l}\text { First branches } \\
\text { height }\end{array}$ & Head diameter & 1000 seed weight & Oil content & $\begin{array}{l}\text { Oil yield per } \\
\text { plant }\end{array}$ \\
\hline $\mathrm{E}$ & $8.755 * * \pm 16.230$ & $12.734 * * \pm 45.859$ & $0.009 \pm 0.009$ & $1.641 * * \pm 2.283$ & $1.363 * * \pm 4.550$ & $0.447 * * \pm 1.038$ \\
\hline $\mathrm{D}$ & $13.253 * * \pm 42.940$ & $54.870 * * \pm 121.332$ & $0.000 \pm 0.025$ & $9.085 * * \pm 6.039$ & $4.312 * * \pm 12.038$ & $6.363 * * \pm 2.746$ \\
\hline $\mathrm{F}$ & $19.500 * * \pm 104.902$ & $57.098 * * \pm 296.415$ & $0.014 \pm 0.061$ & $4.648 * * \pm 14.753$ & $4.739 * * \pm 29.409$ & $9.931 * * \pm 6.709$ \\
\hline $\mathrm{H}_{1}$ & $137.820 * * \pm 109.007$ & $363.282 * * \pm 308.013$ & $0.126 \pm 0.063$ & $25.170 * * \pm 15.331$ & $39.157 * * \pm 30.559$ & $12.734 * * \pm 6.972$ \\
\hline $\mathrm{H}_{2}$ & $118.379 * * \pm 97.378$ & $336.288 * * \pm 275.155$ & $0.097 \pm 0.057$ & $25.072 * * \pm 13.695$ & $35.987 * * \pm 27.299$ & $8.257 * * \pm 6.228$ \\
\hline D- $\mathrm{H}_{1}$ & $-124.567 * * \pm 95.596$ & $-308.412 * * \pm 270.120$ & $-0.125 \pm 0.056$ & $-16.085 * * \pm 13.445$ & $-34.845^{* *} \pm 26.800$ & $-6.371 * * \pm 6.114$ \\
\hline$\left(\mathrm{H}_{1} / \mathrm{D}\right)^{1 / 2}$ & 3.225 & 2.573 & 18.284 & 1.664 & 3.013 & 1.415 \\
\hline$\left(\mathrm{H}_{2} / 4 \mathrm{H}_{1}\right)^{1 / 2}$ & 0.215 & 0.231 & 0.193 & 0.249 & 0.230 & 0.162 \\
\hline $\mathrm{K}_{\mathrm{D}} / \mathrm{K}_{\mathrm{R}}$ & 1.591 & 1.507 & -125.719 & 1.363 & 1.46 & 3.461 \\
\hline$h^{2}$ & $29.128 * * \pm 65.542$ & $0.756 * * \pm 185.198$ & $0.005 \pm 0.038$ & $1.525 * * \pm 9.218$ & $1.787 * * \pm 18.374$ & $-0.248 * *_{ \pm} \pm .192$ \\
\hline $\mathrm{K}$ & 0.246 & 0.002 & 0.051 & 0.061 & 0.050 & -0.030 \\
\hline $\mathrm{GH}$ & 0.430 & 0.493 & 0.462 & 0.580 & 0.501 & 0.504 \\
\hline $\mathrm{DH}$ & 0.080 & 0.133 & 0.003 & 0.251 & 0.098 & 0.581 \\
\hline
\end{tabular}

In this research, positive $\mathrm{F}$ value shows that dominant alleles are greater than the number of recessive alleles. Environmental variance has lower values than genetic variance that explained the importance of determining the genetic effect of studied traits. $\left(\mathrm{H}_{1} / \mathrm{D}\right)^{1 / 2}$ value implied the average degree of dominancy in the population. The degree of $\left(H_{1} / D\right)^{1 / 2}$ plant height, first branches height, head diameter, 1000 seed weight, oil content and oil yield per plant was determined in $3.225,2.573,18.284,1.664$, 3.013 and 1.415 , respectively. These values above 1 showed the over dominance in population. The value of $\mathrm{H}_{2} / 4 \mathrm{H}_{1}$ shows the proportion of positive and negative alleles effects in the parents. In fact, this ratio indicates the multiplication of positive (u) and negative (v) effective alleles. Therefore, in allelic equilibrium $(\mathrm{u}=\mathrm{v}=0.5)$ this ratio (uv) is equal to 0.25 . Dominant and recessive alleles $\left(\mathrm{H}_{2} / 4 \mathrm{H}_{1}\right)$ was found for plant height $(0.215)$, first branches height (2.573), head diameter (0.193), 1000 seed weight $(0.249)$ oil content $(0.230)$ and oil yield per plant $(0.162)$ (Table 4). These results indicate that multiplication of dominant and recessive alleles frequencies was being around 0.25 in terms of plant height, first branches height, 1000 seed weight and oil content, a high enough value for successful phenotypic selection. Ratio of dominant alleles to recessive alleles $(\mathrm{KD} / \mathrm{KR})$ was higher than 1, except for head diameter in studied traits. These results showed that genes operating on these traits were dominant. The value of $\mathrm{h}^{2}$ indicates the proportional size of the variation resulting from the dominance effect in the crosses. $\mathrm{h}^{2}$ was found statistically significant except for head diameter in studied traits. Accordingly, it can be said that heterotopic effects are considerable in the population. Efficiency of selection is interrelated the magnitude of heritability (Kearsey and Pooni, 1996). In population, narrow (DH) and broad heritability (GH) sense obtained 0.080 and
0.430 in plant height, 0.133 and 0.493 in first branches height, 0.003 and 0.462 in head diameter, 0.251 and 0.580 in 1000 seed weight, 0.098 and 0.501 in oil content, 0.581 and 0.504 in oil yield per plant, respectively. Low narrow heritability values were evident on all traits but oil yield per plant, indicating a low response to selection. Mirzahashemi et al. (2014) reported that studied traits had medium narrow-sense heritability that implied on most of the genetic variances, is due to dominance gene action. Arslan (2007) implied that plant height, 1000 seed weight and head diameter could be used to succeed in selection in early generation because of these traits' higher narrow sense heritability degrees. According to result, low narrow sense and significant non-additive gene effects, application of bulk method recommended in early generations.

In Figure 1, the $\mathrm{Wr}-\mathrm{Vr}$ graph of parents, regression line cross the $\mathrm{Wr}$ axis below the point of origin that indicates over dominance studied traits except for first branches height and head diameter. The regression lines for these two traits through the $\mathrm{Wr}$ on positive side (above 0 ), defining presence of a partial dominance. In graphical analysis; parents nearer to the point of the origin inherits dominant alleles to their crosses. Examining of the parents about ranging of regression line, recessive genes by Emek-24 (6), was inherited to their crosses for plant height and oil yield per plant. Genotypes of Emek-16 (2), Emek-24 (6) for first branches height, Es-8517 (1), Emek21 (4) for head diameter, Es-8517 (1), Emek-16 (2), Emek-24 (6) for 1000 seed weight, Es-8517 (1), Emek-16 (2), Ekak-7 (3), Emek-21 (4), Ekay-1 (5) for oil content were closer to the origin and these parents inherited dominant genes to their crosses. 

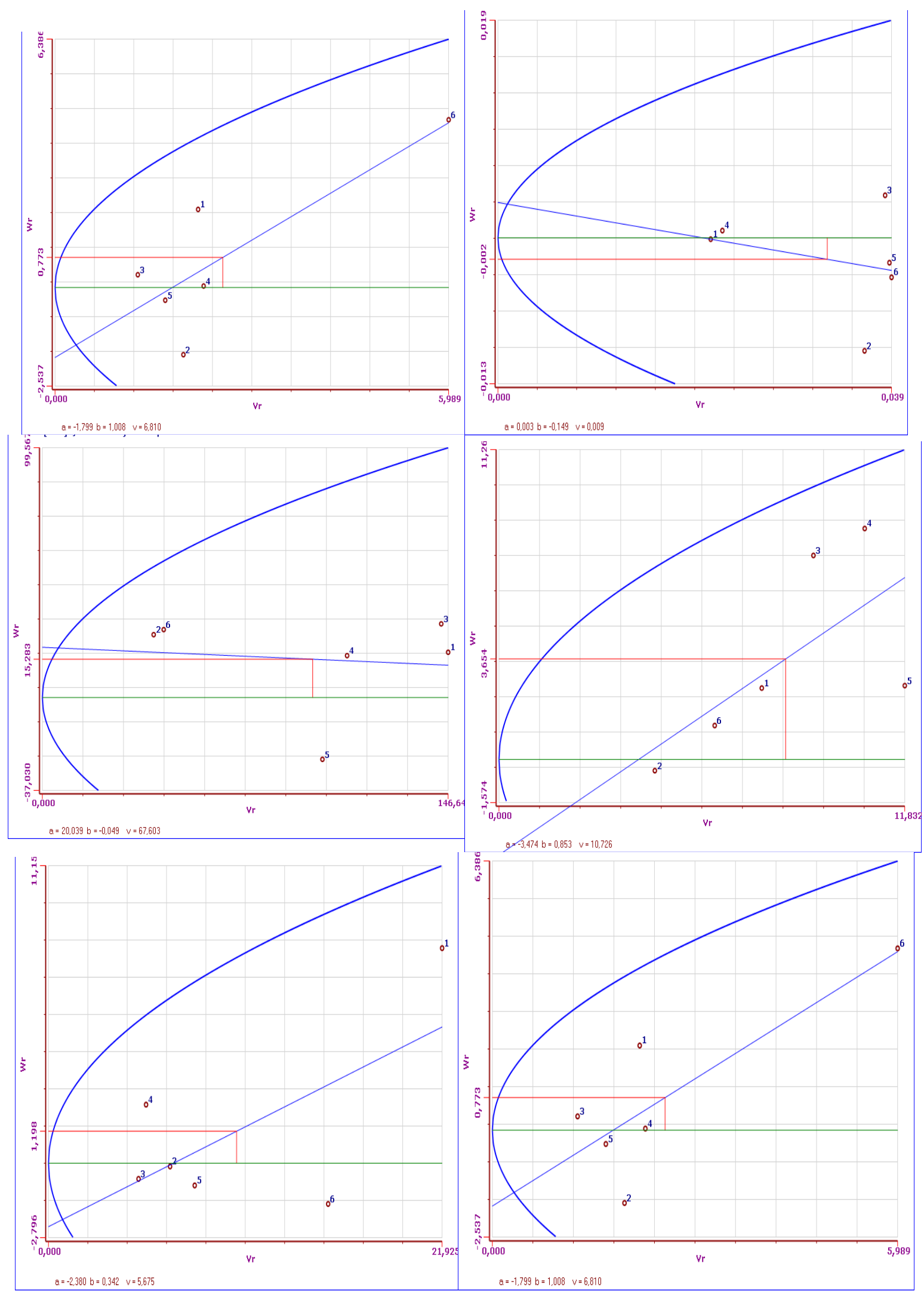

Figure 1. Wr-Vr Graphs about Parents for Investigated Traits: a. Plant height b. First branch height c. Head diameter d. 1000 seed weight e. Oil content f. Oil yield per plant. Parent 1. Es-8517, 2. Emek-16, 3. Ekak-7, 4. Emek-21, 5. Ekay-1, 6. Emek-24 


\section{CONCLUSIONS}

Selection for crosses would be a suitable strategy for oil yield improvement in safflower. Existing dominant gene action and low narrow sense (DH) most of the studied traits in the population, it was decided that to obtain superior plants in this hybrid population selection should be delayed following generation such as $F_{3}$ or $F_{4}$.

\section{LITERATURE CITED}

Arslan, B. 2007. Assessing of heritability and variance components of yield and some agronomic traits of different safflower (Carthamus tinctorius L.) cultivars. Asian J. Plant Science 6:554-557.

Bendjama, A., H. Bouzerzour and A. Benbelkacem. 2014. Adaptability of durum wheat genotypes (Triticum turgidum L. var durum) to contrasted locations. Australian Journal of Basic and Applied Science 8(6): 390-396.

Golkar, P., A. Arzani and A. Rezai. 2012. Genetic analysis of agronomic traits in Safflower (Carthamus tinctorious L.). Notulae Botanicae Horti Agrobotanici Cluj-Napoca 40(1): 276-281.

Golparvar, A. R. 2014. Genetic control and heredity of harvest index and biological yield in Bread Wheat (Triticum aestivum L.). Genetica 4681: 43-48.

Gupta, R. K. and S. B. Singh. 1988. Diallel analysis for seed yield, oil content and other economic traits in safflower (Carthamus tinctorius L.). Genetika-Yugoslavia 20: 161173.
Hayman, B. I. 1954. The theory and analysis of diallel crosses. Genetics 39: 789-809.

Jinks, J. L. and B. I. Hayman. 1953. The analysis of diallel crosses. Maize Cooperation Newsletter 27: 48-54.

Jinks, J. L. 1954. The analysis of continuous variation in a diallel cross of Nicotiana rustica varieties. Genetics 39: 767-788.

Kearsey, M. J. and H. S. Pooni. 1996. The genetical analysis of quantitative traits. New York, Chapman and Hall.

Khan, N. U., G. Hassan, K. B. Marwat, M. B. Farhatullah Kumbhar, N. Khan, A. Parveen, U. Aiman, M. Z. Khan and Z. A. Soomro. 2009. Diallel analysis of some quantitative traits in Gossypium hirsutum L. Pakistan Journal of Botany 41(6): 3009-3022.

Mirzahashemi M., P. Golkar and G. Mohammadi-Nejad. 2014. Gene effects for agronomic traits in Safflower (Carthamus tinctorius L.) under drought stress. Ethno-Pharmaceutical Products 1(1):23-28.

Ozcan, K. and N. Acikgoz. 1999. Populasyon genetiği için bir istatistik paket program geliştirmesi. 3. Tarımda Bilgisayar Uygulamaları Sempozyumu, Çukurova Üniversitesi, 3-6 Ekim, Adana, Türkiye.

Shahbazi E. and G. H. Saeidi. 2007. Genetic analysis for yield components and other agronomic characters in safflower (Carthamus tinctorius L.). Genetic Breeding 36: 11-20.

Yildirim M. B., A. Ozturk, F. Ekiz and H. Puskulcu. 1979. Statistical-genetic methods in plant breeding. Aegean Region Agricultural Research Institute Publications 20:217- 251. 